\title{
Title: Accuracy of parental estimate of child's weight in a paediatric emergency department
}

\section{Abstract:}

Objectives - To determine the accuracy of using parental estimate of a child's weight compared to actual weight in a paediatric emergency setting.

Methods - Prospective, observational study. Age, weight and height data was collected from children aged 1 month up to 11 years with an Australian Triage score of 3 or higher. This was compared with a parent weight estimate. Analysis is descriptive.

Results - 450 children were studied with a mean age of 4 years 4 months. $85.3 \%$ of parents were willing to provide a weight estimate $(\mathrm{N}=384)$. The mean difference between the parent estimate (where provided) and the actual weight was $0.33 \mathrm{~kg}$ (measured weight $>$ estimated; $95 \% \mathrm{Cl}-6.9 \mathrm{~kg}$ to $+7.6 \mathrm{~kg}$ ). There was $75 \%$ agreement within $10 \%$ of the measured weight $(95 \% \mathrm{Cl} 71 \%$ to $79 \%)$ and $92 \%$ agreement within $20 \%$ of the measured weight $(95 \% \mathrm{Cl} 89 \%$ to $95 \%)$. Weight was more commonly underestimated than overestimated. Children of Polynesian/Pacific ethnicity were less likely to have an accurate parental weight estimation.

Conclusions - Parent estimate is an accurate weight estimation method when parents are willing to give an estimate. There is ethnic variation in accuracy which should be taken into account when applying this method.

Key words: weight estimation; children; emergency.

This is the author manuscript accepted for publication and has undergone full peer review but has not been through the copyediting, typesetting, pagination and proofreading process, which may lead to differences between this version and the Version of Record. Please cite this article as doi: 10.1111/1742-6723.13318

This article is protected by copyright. All rights reserved. 


\section{Introduction:}

When a weight cannot be measured during a paediatric emergency, an estimate is used to calculate drug dosage, equipment size and counter shock voltage (1). Without an accurate weight, children could be over- or under-treated. This might negatively impact outcome (2). To date, age-based formulae have been used. In these, all children of the same age are considered to weigh the same, regardless of gender, ethnicity or body habitus (3). Previous studies have shown these formulae to be inaccurate $(4,5)$. A number of methods for weight estimation have been proposed including a height-based tape $(6)$, body habitus adjustments (7-9) and technology-based solutions (10-12). One low-technology method of estimating weight is to ask the parents (13). Previous studies have shown that parents can accurately estimate their child's weight (13-19) when willing to do so. These studies are now over a decade old and may not reflect the current situation.

The parent estimate solution has significant benefits. Pre-hospital providers can communicate this information to destination hospitals so drugs and equipment can be prepared in advance (20). Minimal staff training is required to obtain it (21). However, recent Australian studies show parents do not accurately perceive obesity in their own children (22), and overweight parents are less reliable in identifying the weight status of their children (23-25). With childhood obesity rates rising globally (26), it is important to ensure that any chosen method remains reliable.

This study aims to determine the accuracy of using parental estimate to approximate a child's weight compared to measured weight in a paediatric emergency setting. 


\section{Method:}

This was a prospective, observational study. Data was collected over a three month period from September to November 2018 in the paediatric emergency department (ED) of Sunshine Hospital, Melbourne, Australia. This ED has an annual paediatric census of approximately 25,000 presentations. Data was collected from children aged 1 month up to (but not including) 11 years with an Australian Triage score of 3-5. This age range was selected as the original APLS formula (which at present is the status quo for paediatric weight estimation in Victoria (1)) is restricted to the same age range (5).

Study participants were collected by convenience sampling by the principal investigator who was not blinded to the study hypothesis. Data collected included age, gender, height $(\mathrm{cm})$, weight $(\mathrm{kg})$, ethnicity and parent weight estimate. Parent weight estimate was collected prior to the recording of the child's weight. Weight was measured using National Weighing and Instruments standing scales, the Wedderburn electronic chair scale (model WM401), or the Tanita digital baby weight scale (model BD586). Infants less than 12 months old were measured naked, whilst older children were weighed without shoes or heavy clothing. Height was measured using a stadiometer or a SECA baby measuring mat (model SECA201). Shoes were removed to measure height. In the case of an uncooperative child, weight was measured indirectly by weighing the parent and child together then subtracting the parent's weight. The data form used can be found in the appendix.

Outcomes of interest were agreement between parental estimate of a child's weight and measured weight. Secondary outcomes of interest were agreement within $10 \%$ and $20 \%$ by age group, ethnicity and body mass index (BMI) for children aged 2 years or older ( $\mathrm{N}=258)$. Data was analysed by 
descriptive statistics, Chi square/Fisher Exact for comparison of proportions and Bland-Altman analyses for calculation of mean difference and $95 \%$ limits of agreement.

Ethical approval was granted by the Western Health Low Risk Ethics Panel. All parents verbally consented to participate in the study.

\section{Results:}

A total of 450 children were enrolled into the study. The mean age was 4 years 4 months and the median age was 3 years 7 months. This is consistent with the average age of presentation to the

Sunshine Hospital paediatric ED over the preceding 4-year period. $54.6 \%$ of children were male. Over half (53.3\%) were of non-Caucasian/European ethnicity. BMI was available for 258 children. The demographic of the sample are summarized in Table I.

The majority (85.3\%) of parents were willing provide a weight estimate. Willingness did not appear to be related to the age of the child ( $p$-value 0.6 ), ethnicity ( $p$-value 0.33 ) or gender of the child ( $p$-value 0.17 ). Full data can be found in the appendix.

The mean difference between the parent estimate (where provided) and the actual weight was $0.33 \mathrm{~kg}$

(measured weight $>$ estimated weight; $95 \% \mathrm{Cl}-6.9 \mathrm{~kg}$ to $+7.6 \mathrm{~kg}$ ). The mean percent difference was $1.1 \%$ $(95 \% \mathrm{Cl}-0.5 \%$ to $+2.7 \%)$. There was $75 \%$ agreement within $10 \%$ of the actual weight $(95 \% \mathrm{Cl} 71 \%$ to $79 \%$ ) and $92 \%$ agreement within $20 \%$ of the actual weight (95\% Cl $89 \%$ to $95 \%)$. Weight was more commonly underestimated than overestimated. No significant difference was found between age groups, 
as shown in Table II. The distribution of parental estimate compared to actual weight can be seen in Figure 1.

On multivariate analysis, agreement of the parent estimate within $10 \%$ and $20 \%$ of the actual weight differed by ethnicity (agreement within 10\% $p=0.065$, agreement within $20 \% p=0.01$ ) (Figure 2). Children of Polynesian/Pacific ethnicity were less likely to have agreement of parental weight estimate within $10 \%$ or $20 \%$.

There was a trend towards accuracy of parental estimate varying with BMI category, as shown in Figure

3. This however did not reach statistical significance.

\section{Discussion:}

This study suggests that parental estimate of their child's weight remains an accurate method of weight estimation. This is consistent with findings from previous studies (13-19). The benchmark for sufficient accuracy of weight estimation is not yet known. Previous authors have suggested an estimation method should have $70 \%$ of weight estimates fall within $10 \%$ of actual weight, and $95 \%$ of weight estimates fall within $20 \%$ of actual weight $(5,27)$. Our data shows that the parental estimation method is close to this, with $75 \%$ of weight estimates falling within $10 \%$ of actual weight, and $92 \%$ of weight estimates falling within $20 \%$ of actual weight.

What this study suggests, however, is that the accuracy of parental weight estimates varies with ethnicity and possibly that they become less accurate with increasing BMI. A possible explanation for 
the ethnic variation is that children of Polynesian and Pacific Islander background tend to have higher BMI, compared to other ethnic groups (28). This finding is consistent with previous research which suggests that parents of overweight or obese children are less able to discriminate the weight status of their children (22-25). This could suggest that using parent estimate to estimate children's weight in ED may be less reliable in overweight or obese children.

Research has found that other weight estimation methods, such as age-based formulae or the Broselow tape, also become less accurate with increasing BMI $(5,29)$. Methods that account for body habitus such as the PAWPER XL tape are more reliable in overweight and obese patients (30). These methods may be more labour-intensive and time-consuming. Future guidelines could suggest that parental estimate be used in the first instance with the majority of patients, however if a patient is overweight or obese, or if the parent is unwilling to give an estimate, other methods such as the PAWPER XL tape could be implemented.

There are a number of limitations to this study. First, many children presenting to the ED with non-life threatening illnesses had recently visited a general practitioner where they had been weighed. Some children were weighed regularly at home. Resuscitation scenarios, such as those due to trauma, are often unpredictable and therefore it may be less likely that the child has been weighed recently. Further research in critically ill children is required to see if this changes the accuracy of the parental estimate method. Equally, parents presenting with children to the ED in a non-emergent situation may be less stressed and have better recall of a recent measured weight. Further research in ATS category 1 and 2 children is also required to see if parental stress has an impact on the accuracy of weight estimates. In 
our study, $85.3 \%$ of parents were willing to estimate their child's weight. It would be important to see if parents are more or less willing to estimate their child's weight in a critical emergency scenario, and to determine what the best solution is to use as a backup should a parent be unwilling to guess. This research also does not provide guidance on the accuracy of parental estimate as a weight estimation method for children aged 11 and above.

\section{Conclusion:}

In conclusion, this research adds to the growing body of evidence that suggests that parental estimate is an accurate weight estimation method for children in ED. It raises questions about whether this method would remain accurate in the future should childhood obesity continue to rise. Further research on children in critical scenarios is required to see if this method is fit-for-purpose in those scenarios where it would be required. 


\section{References:}

1. The Royal Childrens Hospital Melbourne. Major paediatric trauma - the primary survey. Clinical Practice Guidelines [cited 15 January 2019]. Available from:

www.rch.org.au/clinicalguide/guideline_index/Major_paediatric_trauma_the_primary_survey/

2. Cella M, Knibbe C, Danhof M, Pasqua OD. What is the right dose for children? $\mathrm{Br} \mathrm{J}$ Clin Pharmacol. 2010;70(4):597-603.

3. Wells M, Goldstein LN, Bentley A. The accuracy of emergency weight estimation systems in children - a systematic review and meta-analysis. Int J Emerg Med. 2017;10(1):29.

4. Young KD, Korotzer NC. Weight estimation methods in children: a systematic review. Ann Emerg Med. 2016;68(4):441-51.

5. Wells M, Goldstein LN, Bentley A. It is time to abandon age-based emergency weight estimation in children! A failed validation of 20 different age-based formulas. Resuscitation. 2017;116(7):73-83.

6. Wells M, Goldstein LN, Bentley A, Basnett S, Monteith I. The accuracy of the Broselow tape as a weight estimation tool and dosing guide - a systematic review and meta-analysis. Resuscitation. 2017;121:9-33.

7. Choi JY. Validation of the mid-arm-based weight estimation formula (the Cattermole formula) for Korean children. Resuscitation. 2018;132:13-16.

8. Wells M. A validation study of the PAWPER XL tape for both total body weight estimation in preschool children from low- and middle-income countries. PLoS ONE. 2019;14(1):e0210332.

9. Schmidt AR, Buehler PK, Meyer J, Weiss M, Schmitz A, Both CP. Length-based body weight estimation in paediatric patients: the impact of habitus - a clinical observational trial. Acta Anaesthesiological Scandinavica. 2018;62(10)1389-95.

10. Wetzel O, Schmidt AR, Seiler M, Scaramuzza D, Seifert B, Spahn DR, Stein P. A smartphone application to determine body length for body weight estimation in children: a prospective clinical trial. J Clin Monit Comput. 2018;32(3):571-8.

11. Wells M, Goldstein L, Bentley A. The accuracy of paediatric weight estimation during simulated emergencies: the effects of patient position, patient cooperation and human errors. Afr J Emerg Med. 2018;8(2):43-50.

12. Appelbaum N, Clarke J, Machonochie I, Darzi A. Paediatric weight estimation by age in the digital era: optimising a necessary evil. Resuscitation. 2018;122:29-35.

13. Krieser D, Nguyen K, Kerr D, Jolley D, Clooney M, Kelly AM. Parental weight estimation of their child's weight is more accurate than other weight estimation methods for determining children's weight in an emergency department? Emerg Med J. 2007;24(11):756-9.

14. Patel A, Zikos V, Rzechula K, McQuillen K. The accuracy of pediatric weight in the Emergency Department: do caregiver weight estimates measure up? Ann Emerg Med. 2007;50(3,Supplement):S1234.

15. Zink K, Bohn M, Hood T, Topp RV, Berger J. A comparison of methods of assessing patient body weight in pediatric emergency department. Kentucky Nurse. 2008;56(3):12.

16. Partridge RL, Abramo TJ, Haggarty KA, Hearn R, Sutton KL, An AQ, et al. Analysis of parental and nurse weight estimates of children in the pediatric emergency department. Pediatr Emerg Care.

2009;25(12):816-8. 
17. Huybrechts I, Himes JH, Ottevaere C, De Vriendt T, De Keyzer W, Cox B, et al. Validity of parent-reported weight and height of preschool children measured at home or estimated without home measurement: a validation study. BMC Pediatr. 2011;11:63.

18. Trakulsrichai S, Boonsri C, Chathaipun P, Chunharas A. Accuracy of three methods used for Thai children's body weight estimation. J Med Assoc Thail. 2012;95(9):1194-9.

19. Nosaka N, Fujiwara T, Knaup E, Okada A, Tsukahara H. Validity of mothers' reports of children's weight in Japan. Acta Med Okayama. 2016;70(4):255-9.

20. Chassee T, Reischmann D, Mancera M, Hoyle JD. Emergency medical dispatchers can obtain accurate pediatric weights from 911 callers. Prehospital Emerg Care. 2016;20(6):808-14.

21. Abdel-Rahman S, Jacobsen R, Watts JL, Doyle SL, O'Malley DM, Hefner TD, Dowd MD. Comparative performance of paediatric weight estimation techniques: a human factor errors analysis. Pediatr Emerg Care. 2017;33(8):548-552.

22. Wake M, Kerr JA, Jansen PW. Child BMI over time and parent-perceived overweight. Paediatrics. 2018;142(6):e20173985.

23. Huang JS, Becerra K, Oda T, Walker E, Xu R, Donohue M, Chen I, Curbelo V, Breslow A. Parental ability to discriminate the weight status of children: results of a survey. Paediatrics. 2007;120(1):e112-9.

24. Warschburger $P$, Kröller K. Maternal perception of weight status and health risks associated with obesity in children. Paediatrics. 2009;124(1):e60-8.

25. Nemecek D, Sebelfsky C, Woditschka A, Voitl P. Overweight in children and its perception by parents: cross-sectional observation in a general paediatric outpatient clinic. BMC Paediatrics. 2017;17(212):1-10.

26. Commission on Ending Childhood Obesity. Facts and figures on childhood obesity. World Health Organisation. 2017 [cited 14 January 2019]. Available from: www.who.int/end-childhood-obesity/facts/en/

27. Wells M, Goldstein L, Bentley A. Development and validation of a method to estimate bodyweight in critically ill children using length and mid-arm circumference measurements - the PAWPER XL-MAC system. S Afr Med J. 2017;107(11):1-7.

28. Crowell DH, Rudoy R, Nigg CR, Sharma S, Baruffi G. Perspective on racial-ethnic birth weight. Hawaii Med J. 2010;69(9):216-220.

29. Tanner D, Negaard A, Huang R, Evans N, Hennes H. A prospective evaluation of the accuracy of weight estimation using the Broselow tape in overweight and obese pediatric patients in the emergency department. Pediatr Emerg Care. 2017;33(10):675-678.

30. Wells M, Goldstein LN, Bentley A. A validation study of the PAWPER XL tape: accurate estimation of both total and ideal body weight in children up to 16 years of age. Trauma Emerg Care. 2017;2(5):1-8. 
Table 1: Demographic data

\begin{tabular}{l|l} 
Total & 450 candidates
\end{tabular}

Gender $(\mathrm{N}=450)$

\begin{tabular}{l|l} 
Male & $246(54.6 \%)$
\end{tabular}

Female

$197(43.8 \%)$

Not recorded

$7(1.6 \%)$

Age $(\mathrm{N}=450)$

\begin{tabular}{l|c}
$<1$ years & $52(11.6 \%)$ \\
\hline $1-4$ years & $223(49.6 \%)$ \\
\hline $5-10$ years & $175(38.9 \%)$
\end{tabular}

Ethnicity $(\mathrm{N}=450)$

Caucasian/ European

$211(46.9 \%)$

African

$38(8.4 \%)$

This article is protected by copyright. All rights reserved. 


\begin{tabular}{|c|c|}
\hline Asian & $81(18 \%)$ \\
\hline Polynesian/ Pacific Islander & $22(4.9 \%)$ \\
\hline Indian subcontinent & $65(14.4 \%)$ \\
\hline Other & $13(2.9 \%)$ \\
\hline Not recorded & $20(4.4 \%)$ \\
\hline Body mass index (only children aged 2 and above, $\mathbf{N}=\mathbf{2 5 8})$ \\
\hline$<14$ & $22(8.6 \%)$ \\
\hline $14-17$ & $126(48.8 \%)$ \\
\hline $17-20$ & $77(29.8 \%)$ \\
\hline$>20$ & $33(12.8 \%)$ \\
\hline
\end{tabular}

This article is protected by copyright. All rights reserved. 
Table 2: Accuracy of the parent estimate compared to actual weight by age

\begin{tabular}{|c|c|c|c|c|c|}
\hline & $\begin{array}{l}\text { Mean } \\
\text { difference } \\
(\mathbf{k g})\end{array}$ & $\begin{array}{l}95 \% \text { limits of } \\
\text { agreement } \\
\text { (kg) }\end{array}$ & $\begin{array}{l}\text { Mean percent } \\
\text { difference }\end{array}$ & $\begin{array}{l}\text { Agreement } \\
\text { within } 10 \%\end{array}$ & $\begin{array}{l}\text { Agreement } \\
\text { within } 20 \%\end{array}$ \\
\hline Overall & $\begin{array}{l}0.33 \\
\text { (measured } \\
\text { weight > } \\
\text { estimated) }\end{array}$ & -6.9 to +7.6 & $\begin{array}{l}1.1 \% \\
{[-0.5 \text { to }+2.7 \%]}\end{array}$ & $\begin{array}{l}75 \% \\
{[71-79 \%]}\end{array}$ & $\begin{array}{l}92 \% \\
{[89-95 \%]}\end{array}$ \\
\hline Age $<1$ years & $\begin{array}{l}0.18 \\
\text { (measured } \\
\text { weight > } \\
\text { estimated) }\end{array}$ & -1.12 to +0.76 & $\begin{array}{l}2.4 \% \\
{[-0.8 \text { to }+4.1 \%]}\end{array}$ & $\begin{array}{l}42 / 47 ; 89 \% \\
{[77-95 \%]}\end{array}$ & $\begin{array}{l}47 / 47 ; 100 \% \\
{[92-100 \%]}\end{array}$ \\
\hline Age 1-4 years & $\begin{array}{l}0.23 \\
\text { (measured } \\
\text { weight > } \\
\text { estimated) }\end{array}$ & -1.75 to +2.21 & $\begin{array}{l}1.4 \% \\
{[-0.4 \text { to }+2.4 \%]}\end{array}$ & $\begin{array}{l}\text { 148/189; } 78 \% \\
{[72-84 \%]}\end{array}$ & $\begin{array}{l}\text { 173/189; } 92 \% \\
{[86-95 \%]}\end{array}$ \\
\hline $\begin{array}{l}\text { Age 5-10 } \\
\text { years }\end{array}$ & $\begin{array}{l}0.8 \\
\text { (measured } \\
\text { weight > } \\
\text { estimated) }\end{array}$ & -8.54 to +10.1 & $\begin{array}{l}2.3 \% \\
{[-0.1 \text { to } 4.8 \%]}\end{array}$ & $\begin{array}{l}\text { 107/147; 71\% } \\
{[64-78 \%]}\end{array}$ & $\begin{array}{l}\text { 135/147; 91\% } \\
{[85-95 \%]}\end{array}$ \\
\hline
\end{tabular}

Square brackets enclose $95 \%$ confidence interval

This article is protected by copyright. All rights reserved. 


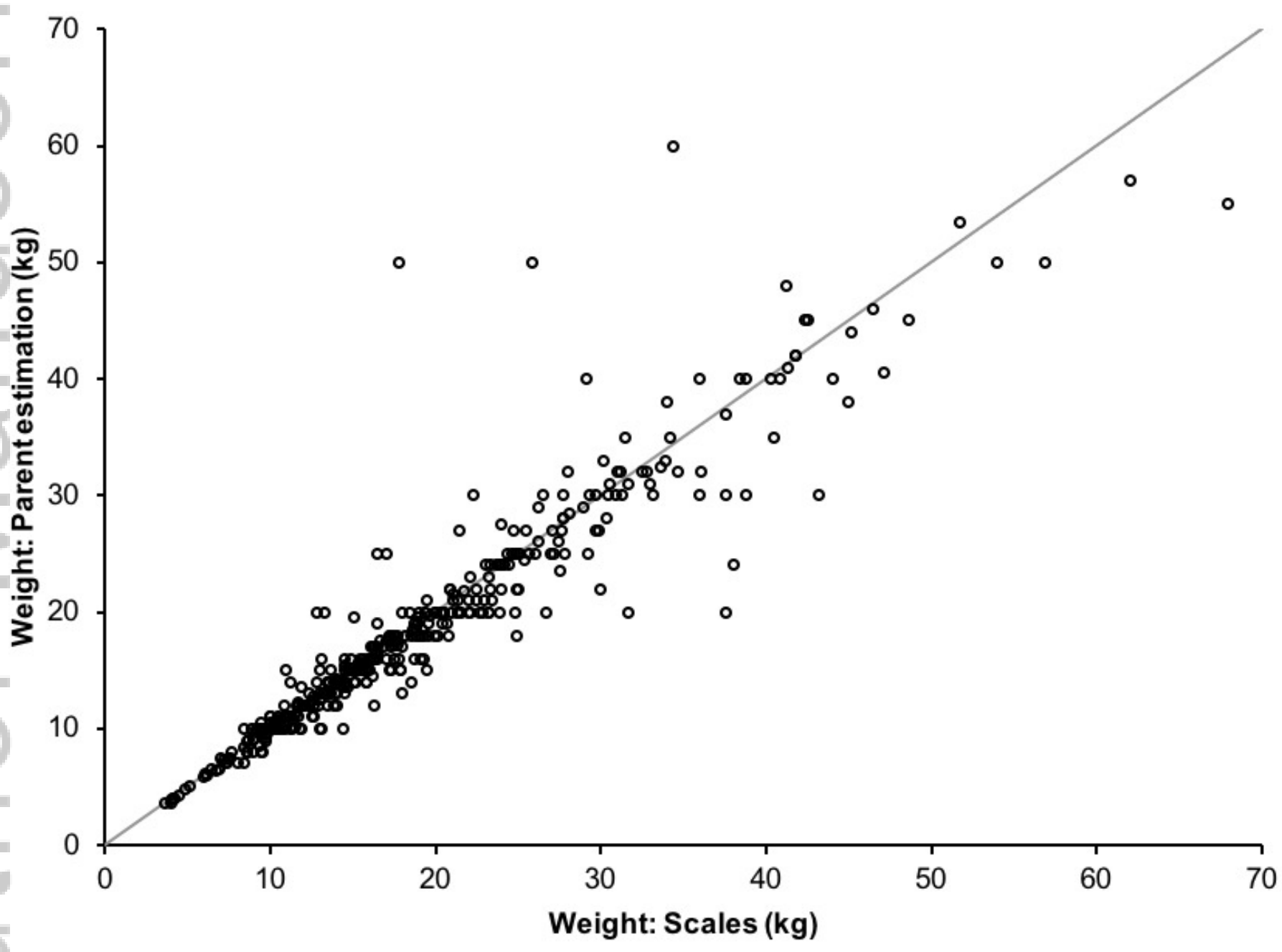

EMM_13318_Figure 1.jpg

This article is protected by copyright. All rights reserved. 
$100 \%$

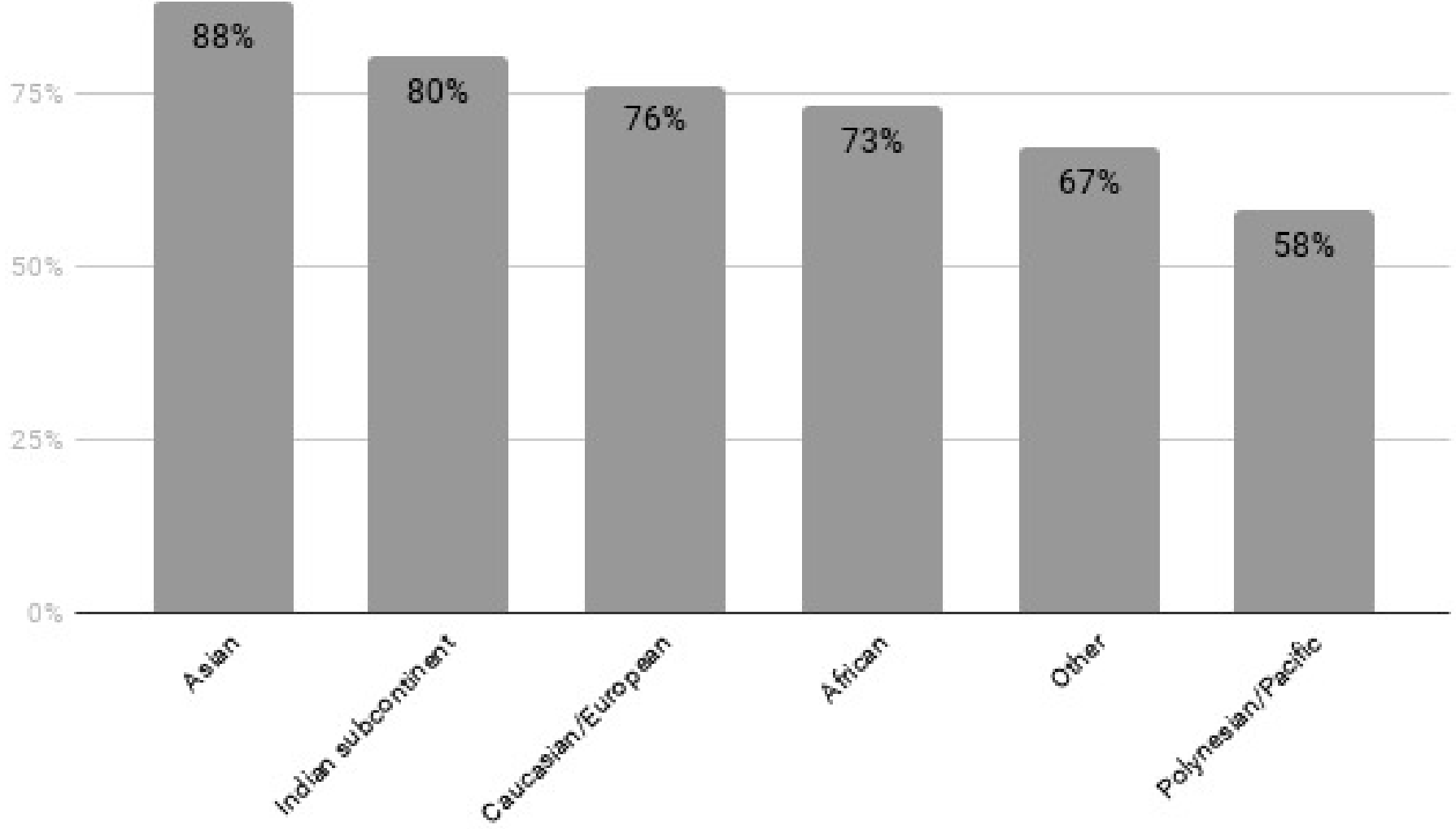

EMM_13318_Figure 2.jpg

This article is protected by copyright. All rights reserved. 
Table 1: Demographic data

\begin{tabular}{|c|c|}
\hline Total & 450 candidates \\
\hline \multicolumn{2}{|l|}{ Gender $(\mathrm{N}=450)$} \\
\hline Male & $246(54.6 \%)$ \\
\hline Female & $197(43.8 \%)$ \\
\hline Not recorded & $7(1.6 \%)$ \\
\hline \multicolumn{2}{|l|}{ Age $(\mathrm{N}=450)$} \\
\hline$<1$ years & $52(11.6 \%)$ \\
\hline $1-4$ years & $223(49.6 \%)$ \\
\hline $5-10$ years & $175(38.9 \%)$ \\
\hline \multicolumn{2}{|l|}{ Ethnicity $(\mathrm{N}=450)$} \\
\hline Caucasian/ European & $211(46.9 \%)$ \\
\hline African & $38(8.4 \%)$ \\
\hline Asian & $81(18 \%)$ \\
\hline Polynesian/ Pacific Islander & $22(4.9 \%)$ \\
\hline Indian subcontinent & $65(14.4 \%)$ \\
\hline Other & $13(2.9 \%)$ \\
\hline Not recorded & $20(4.4 \%)$ \\
\hline \multicolumn{2}{|c|}{ Body mass index (only children aged 2 and above, $N=258$ ) } \\
\hline$<14$ & $22(8.6 \%)$ \\
\hline $14-17$ & $126(48.8 \%)$ \\
\hline $17-20$ & $77(29.8 \%)$ \\
\hline$>20$ & $33(12.8 \%)$ \\
\hline
\end{tabular}

This article is protected by copyright. All rights reserved. 
Table 2: Accuracy of the parent estimate compared to actual weight by age

\begin{tabular}{|c|c|c|c|c|c|}
\hline - & Mean difference $(\mathbf{k g})$ & $\begin{array}{l}\text { 95\% limits of } \\
\text { agreement (kg) }\end{array}$ & $\begin{array}{l}\text { Mean percent } \\
\text { difference }\end{array}$ & $\begin{array}{l}\text { Agreement within } \\
10 \%\end{array}$ & $\begin{array}{l}\text { Agreement within } \\
20 \%\end{array}$ \\
\hline Overall & $\begin{array}{l}0.33 \\
\text { (measured weight }> \\
\text { estimated) }\end{array}$ & -6.9 to +7.6 & $\begin{array}{l}1.1 \% \\
{[-0.5 \text { to }+2.7 \%]}\end{array}$ & $\begin{array}{l}75 \% \\
{[71-79 \%]}\end{array}$ & $\begin{array}{l}92 \% \\
{[89-95 \%]}\end{array}$ \\
\hline Age $<1$ years & $\begin{array}{l}0.18 \\
\text { (measured weight }> \\
\text { estimated) }\end{array}$ & -1.12 to +0.76 & $\begin{array}{l}2.4 \% \\
{[-0.8 \text { to }+4.1 \%]}\end{array}$ & $\begin{array}{l}42 / 47 ; 89 \% \\
{[77-95 \%]}\end{array}$ & $\begin{array}{l}47 / 47 ; 100 \% \\
{[92-100 \%]}\end{array}$ \\
\hline Age $1-4$ years & $\begin{array}{l}0.23 \\
\text { (measured weight }> \\
\text { estimated) }\end{array}$ & -1.75 to +2.21 & $\begin{array}{l}1.4 \% \\
{[-0.4 \text { to }+2.4 \%]}\end{array}$ & $\begin{array}{l}148 / 189 ; 78 \% \\
{[72-84 \%]}\end{array}$ & $\begin{array}{l}173 / 189 ; 92 \% \\
{[86-95 \%]}\end{array}$ \\
\hline Age 5-10 years & $\begin{array}{l}0.8 \\
\text { (measured weight }> \\
\text { estimated) }\end{array}$ & -8.54 to +10.1 & $\begin{array}{l}2.3 \% \\
{[-0.1 \text { to } 4.8 \%]}\end{array}$ & $\begin{array}{l}107 / 147 ; 71 \% \\
{[64-78 \%]}\end{array}$ & $\begin{array}{l}135 / 147 ; 91 \% \\
{[85-95 \%]}\end{array}$ \\
\hline
\end{tabular}

\section{Square brackets enclose $95 \%$ confidence interval}


Title: Accuracy of parental estimate of child's weight in a paediatric emergency department Running title: "Accuracy of parental estimate"

\section{Authors:}

Mieke Foster, BMedSci

Dr. Andrew Tagg, MBBS, FACEM

\section{Sharon Klim, BN}

Professor Anne-Maree Kelly, MD, FACEM

Institution:

Joseph Epstein Centre for Emergency Medicine Research

Western Health - Sunshine Hospital

176 Furlong $\mathrm{Rd}$

St Albans VIC 3021

Correspondence:

Mieke Foster

Email: mlfoster@deakin.edu.au

Telephone: 0411810007

Address: Joseph Epstein Centre for Emergency Medicine Research

Western Health - Sunshine Hospital

176 Furlong Rd

St Albans VIC 3021

MF - Came up with the original study design, collected the data and wrote the initial draft AT - Assisted with data collection and writing of the document SK - Assisted with ethics approval and data collection

AMK - Provided core oversight, helped with the ethics approval and data analysis

Word count: 2,475 words 


\section{University Library}

\section{- M M N E R VA A gateway to Melbourne's research publications}

Minerva Access is the Institutional Repository of The University of Melbourne

Author/s:

Foster, M;Tagg, A;Klim, S;Kelly, A-M

Title:

Accuracy of parental estimate of child's weight in a paediatric emergency department

Date:

2019-12-01

Citation:

Foster, M., Tagg, A., Klim, S. \& Kelly, A. -M. (2019). Accuracy of parental estimate of child's weight in a paediatric emergency department. EMERGENCY MEDICINE AUSTRALASIA, 31 (6), pp.1059-1063. https://doi.org/10.1111/1742-6723.13318.

Persistent Link:

http://hdl.handle.net/11343/285928 